The $9^{\text {th }}$ International Conference of Veterinary Research Division National Research Centre, Giza, Egypt $27^{\text {th }}-29^{\text {th }}$ September 2021

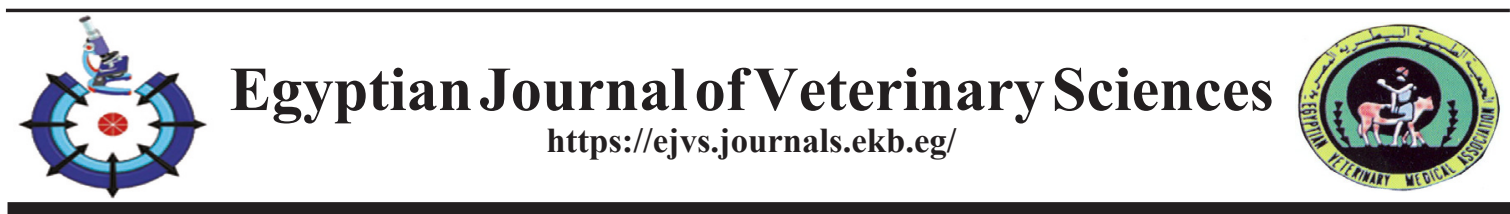

\title{
Effect of Folic Acid on Some Biochemical Parameters in Female Rabbits Treated Experimentally with Methotrexate
}

\author{
Khalid Ahmed Hadi'* , Alyaa Salih Jawad² , Shireen Farok Shaker³, Ahmed \\ Abdulaali Azeez ${ }^{4}$ \\ ${ }^{1}$ Department of physiology, pharmacology and biochemistry, Veterinary Medicine \\ faculty, Tikrit University, Tikrit, Iraq \\ ${ }^{2}$ Department of immediate ambulance, Al-Dour Technical Institute, Northern \\ Technical University, Salah-aldeen, Iraq \\ ${ }^{3}$ Department of chemistry, sciences faculty, Tikrit University, Tikrit, Iraq \\ ${ }^{4}$ Department of Physiology, Pharmacology and Biochemistry, faculty of Veterinary \\ Medicine, University of Kirkuk, Kirkuk, Iraq.
}

\begin{abstract}
$\mathbf{T}$ HE present study was carried out to investigate the effect of folic acid (FA) on the some biochemical parameters of female rabbit's treated and non-treated with methotrexate (MTX). Twenty female rabbits were divided in to four groups,control group 5 rabbits were received distilled water, (FA) group rabbits were received folic acid at $0.07 \mathrm{mg} / \mathrm{kg}$ body weight orally, Methotrexate group : 5 rabbits were received methtrexate $(0.03 \mathrm{mg} / \mathrm{kg}$ body weight orally ) three times a week and (FA) with (MTX) group : 5 rabbits were received folic acid $(0.07 \mathrm{mg} / \mathrm{kg}$ body weight orally) daily and (MTX) $(0.03 \mathrm{mg} / \mathrm{kg}$ body weight orally) three times a week. The drugs were given by intubation. The experiment was last for 9 weeks. Blood sample were collected after nine weeks of the experiment to study the following biochemical parametersbilirubin in serum, unbound Iron Binding Capacity (UIBC), Total Iron Binding Capacity $(\mu \mathrm{g} / \mathrm{dl})$, Total Serum Iron and Ferritinconcentration in serum. The results of MTX group reveal high significant decrease $(\mathrm{P} \geq 0.05)$ bilirubin conc. At the same time there is a significant increase in total SI, TIBC, UIBC in this group. The group of animals received FA with MTX showed a good prognosis with health improvement characterized by high significant changes in all studied parameters to return back to their normal values.It was concluded that (FA) is administration with MTX very important to correct these changes and the animals return to normal conditions. More work is needed to study the effects of these drugs on other systems in the body.
\end{abstract}

Keywords: Folic acid, biochemical parameters, female rabbits, methotrexate.

\section{Introduction}

Micronutrients include vitamins and minerals that our bodies require them in small quantities and their deficiency will produce abnormal functions of cells and organs [1]. (FA) is a synthetic folate compound also known generically as folate or folacin, pteroylglutamic acid (PGA), is a member of the B-complex family of vitamins, and works in concert with vitamin B12 [2]. (FA) functions primarily as a methyl-group donor in transferring one carbon atom involved in many important body processes, including building blockers of DNA and RNA needed for protein synthesis [3]. Therefore, rapidly growing tissues, such as those of a fetus, and rapidly

*Corresponding auther: E-mail: Khalid Ahmed Hadi, Dr.physiologist@tu.edu.iq, Tel: +9647702315766

(Received 02/06/2021; accepted 14/09/2021)

DOI. 10.21608/ejvs.2021.78840.1237

(C)2021 National Information and Documentation Center (NIDOC) 
regenerating cells, like red blood cells have a high need for (FA) [4]. Therapeutically, folic acid is instrumental in reducing homocysteine levels and the occurrence of neural tube defects [5]. It may play a key role in preventing cervical dysplasia and protecting against neoplasia in ulcerative colitis. Folic acid also shows promise as part of a nutritional protocol to treat vitiligo, and may reduce inflammation of the gingiva [6]. Furthermore, certain neurological, cognitive [7] and psychiatric presentations may be secondary to folate deficiency [8]. Such presentations include peripheral neuropathy, myelopathy, restless legs syndrome, insomnia, dementia, forgetfulness, irritability, endogenous depression, organic psychosis, and schizophrenia-like syndromes [9]. Green vegetables and certain (citrus) fruits are important natural dietary sources of folates [10]. MTX and formerly known as amethopterin, is an antimetabolite and antifolate drug used in treatment of cancer and autoimmune diseases [11]. It acts by inhibiting the metabolism of (FA). MTX replaced the more powerful and toxic antifolate aminopterin, and the two should not be confused with each other, Its mechanism of action is inhibiting the conversion of inactive folate [dihydrofolate (DHF)] to active folate [tetrahydrofolate (THF)] [12]. Therefore, this study was designed to investigate the effect of folic acid on biochemical parameters in female rabbits. It also aimed to study the effect of folic acid deficiency due to MTX treatment on studied biochemical parameters.

\section{$\underline{\text { Materials }}$}

Animals

A total of twenty female rabbits were used in this study. They were at age 4-5 months. Their body weight ranged between 1-1,200 $\mathrm{Kg}$. All animals were kept in the same suitable environmental conditions of $25-27{ }^{\circ} \mathrm{C}$, and photoperiod of 12 hours daily. The animals were housed in plastic cages of $90 \times 60 \times 30 \mathrm{~cm}$ in diameter. These cages were cleaned once a week. The food (pellets) and water (tap water) was given freely. The animals kept at least 2 weeks for adaptation before starting the study.

\section{Methods}

\section{Experimental Design}

A total of 20 female rabbits were divided into 4 groups equally as follow:

1. Control (C) group: Five rabbits were received distilled water.
2. Folic acid (F) group: Five rabbits were received folic acid at $0.07 \mathrm{mg} / \mathrm{kg}$ body weight daily [13].

3. Methotrexate (M) group: Five rabbits were received methotrexate $(0.03 \mathrm{mg} / \mathrm{kg}$ body weight) three times a week [13].

4. Folic acid and Methotrexate (FM) group: Five rabbits were received (FA) $(0.07 \mathrm{mg} / \mathrm{kg}$ body weight) daily and methotrexate $(0.03 \mathrm{mg} / \mathrm{kg}$ body weight) three times a week.

The drugs were given by intubation. The experiment was last for 9 weeks.

\section{Blood Collection}

Blood samples were obtained via cardiac puncture technique from each animal using disposable syringe $5 \mathrm{ml}$ with needles $22 \mathrm{G}$. These samples were centrifuged at $2500 \mathrm{round} /$ minute (rpm) for 15 minute and then serum sample were stored in freezer at $-18^{\circ} \mathrm{C}$ until they were used for ferritin, Tiron, TIBC and bilirubine tests.

\section{Dosage and Preparation \\ Dose of (FA)}

The dose of folic acid was used according to Woo [13]. One tablet of (FA) (5mg) dissolved in $714 \mathrm{ml}$ of distilled water to obtain $0.07 \mathrm{mg} / \mathrm{kg} \mathrm{BW}$ of folic acid in each $\mathrm{ml}(0.007 \mathrm{mg} / 100 \mathrm{~g} \mathrm{BW} / \mathrm{ml})$.

\section{Dose of (MTX)}

The MTX dose was used as $0.03 \mathrm{mg} / \mathrm{kg} \mathrm{BW}$ by dissolving one tablet of MTX $(2.5 \mathrm{mg})$ in $833 \mathrm{ml}$ of distilled to obtain $0.003 \mathrm{mg} / \mathrm{kgBW}$ in each one $\mathrm{ml}(0.003 \mathrm{mg} / 100 \mathrm{gBW} / \mathrm{ml})$ [14].

\section{Biochemical parameters Serum ferritin concentration}

For the quantitative determination for ferritin concentration in blood,ferritin enzyme immunoassay test kit was used. This test is based on a solid phase enzyme-linked immunosorbent assay (ELISA). The concentration of ferritin is directly proportional to the color intensity of the test sample [15].

\section{Total Serum Iron}

The $\mathrm{Fe}^{+3}$ bound to serum ferritin once dissociated in a week-acid medium by teepol and guanidium chloride then is reduced by hydroxylamine to $\mathrm{Fe}^{+2}$. The ferrous ion forming a colored complex with ferrozine proportional to the concentration of iron present in the sample [16].

This measurement takes place by colorimetric method by the following steps: 


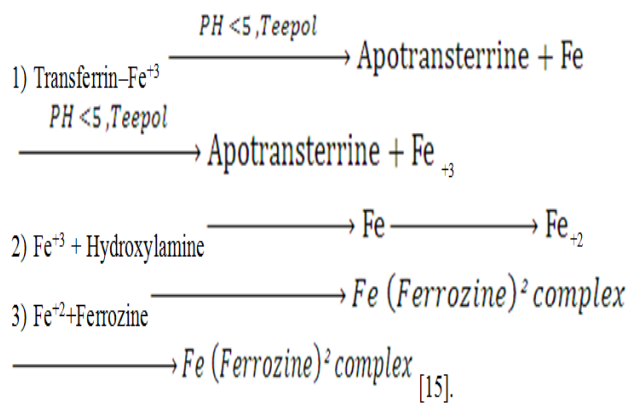

Total Iron Binding Capacity $(\mu \mathrm{g} / \mathrm{dl})$

Serum iron $\left(\mathrm{Fe}^{+3}\right)$ is bound to transferrin. The amount of iron that serum transferrin can bind when complety saturated with an excess of $\left(\mathrm{Fe}^{+3}\right)$ is the total iron binding capacity (TIBC). A special kit is used for measuring TIBC by colorimetric method at $560 \pm 20 \mathrm{~nm}[16]$.

Unbound Iron Binding Capacity (UIBC)

UIBC was estimated by numeric differences between TIBC \& SI is the amount of Iron Binding Capacity remaining on the transferring or the Unbound Iron Binding Capacity [17].

\section{Serum Bilirubin}

Bilirubin meter and non-heparinized Microhematocrit tubes were used for this determination. Standardization by distilled water at the beginning and after each test was done. The capillary tube containing the sample after centrifugation can be inserted on the serum gauge and then the optical density for each sample was recorded within seconds [18].

\section{Results and Discussion}

\section{Ferritin, SI, TIBC and UIBC in serum}

Table (1) ferritin, SI, TIBC and UIBC and bilirubin concentration in female rabbits after nine weeks of treatment. This table shows that ferritin level deceases significantly in MTX group as a compared with control and FM groups due to folate deficiency. MTX inhibit the conversion of inactive dihydrofolate to active form tetrahydrofolate by inhibition THFR enzyme and act by blocking DNA and RNA synthesis causing intestinal mucositis [19]. This may be due to malabsorption of iron from the GIT that results as a side effect of MTX treatment [20].

TABLE 1. Ferritin, total serum iron (SI), total iron binding capacity (TIBC) and unbound iron-binding capacity (UIBC) and bilirubin concentration for $\operatorname{control}(\mathrm{C})$, methotrexate $(\mathrm{M})$, folic acid $(\mathrm{F})$, and methotrexate + folic acid (FM) groups after nine weeks of the experiment in female rabbits .

\begin{tabular}{|c|c|c|c|c|}
\hline Group & $\begin{array}{c}\text { Group (C) } \\
\text { Control } \\
\text { group }\end{array}$ & $\begin{array}{c}\text { Group (M) } \\
\text { MTX } \\
(0.03 \mathrm{mg} / \mathrm{kg}) \\
\text { three time a week }\end{array}$ & $\begin{array}{c}\text { Group (F) } \\
\text { FA } \\
(0.07 \mathrm{mg} / \mathrm{kg}) \\
\text { daily }\end{array}$ & $\begin{array}{c}\text { Group (FM) } \\
\text { MTX + FA } \\
(0.03 \mathrm{mg} / \mathrm{kg} \text { three time } \\
\text { a week })+(0.07 \mathrm{mg} / \mathrm{kg} \\
\text { daily })\end{array}$ \\
\hline $\begin{array}{l}\text { Ferritin } \\
(\mathrm{ng} / \mathrm{ml})\end{array}$ & $\begin{array}{c}10.2 \pm 0.09 \\
\mathrm{~A}\end{array}$ & $\begin{array}{c}8.1 \pm 0.09 \\
\mathrm{C}\end{array}$ & $\begin{array}{c}7.2 \pm 0.06 \\
\mathrm{D}\end{array}$ & $\begin{array}{c}9.2 \pm 0.09 \\
\text { B }\end{array}$ \\
\hline $\begin{array}{c}\mathrm{SI} \\
(\mathrm{mg} / \mathrm{dl})\end{array}$ & $\begin{array}{c}433.6 \pm 6.01 \\
\mathrm{D}\end{array}$ & $\begin{array}{c}683.8 \pm 12.33 \\
\mathrm{~A}\end{array}$ & $\begin{array}{c}489.4 \pm 13.12 \\
C\end{array}$ & $\begin{array}{c}523.6 \pm 8.92 \\
\text { B }\end{array}$ \\
\hline $\begin{array}{c}\text { TIBC } \\
(\mathrm{mg} / \mathrm{dl})\end{array}$ & $\begin{array}{c}937.6 \pm 13.3 \\
\text { B }\end{array}$ & $\begin{array}{c}1467.0 \pm 12.3 \\
\mathrm{~A}\end{array}$ & $\begin{array}{c}561.2 \pm 17.1 \\
\mathrm{D}\end{array}$ & $735.2 \pm 13.2$ \\
\hline $\begin{array}{l}\text { UIBC } \\
(\mathrm{mg} / \mathrm{dl})\end{array}$ & $\begin{array}{c}475.6 \pm 5.81 \\
\text { B }\end{array}$ & $\begin{array}{c}765.2 \pm 17.81 \\
\mathrm{~A}\end{array}$ & $\begin{array}{c}54.8 \pm 2.66 \\
\mathrm{D}\end{array}$ & $\begin{array}{c}302.4 \pm 11.49 \\
\mathrm{C}\end{array}$ \\
\hline $\begin{array}{l}\text { Bilirubin } \\
(\mathrm{mg} / \mathrm{dl})\end{array}$ & $\begin{array}{c}0.51 \pm 0.01 \\
\mathrm{~A}\end{array}$ & $\begin{array}{c}0.33 \pm 0.01 \\
\mathrm{D}\end{array}$ & $\begin{array}{c}0.36 \pm 0.04 \\
\mathrm{C}\end{array}$ & $\begin{array}{c}0.44 \pm 0.01 \\
\text { B }\end{array}$ \\
\hline
\end{tabular}

Values represent mean \pm SE.

Different capital letter indicate significant differences $(\mathrm{P} \leq 0.05)$ between groups.Control group, MTX, FA andMTX + FA

A highest significant value when compare it with other groups .

$B$ less significant value than A.

C lesssignificant value than $B$.

D lowest significant value when compare it with other groups . 
The decrease in ferritin level in FA group as compared with other groups may be dueto high consumption of iron in $\mathrm{RBCs}$ and $\mathrm{Hb}$ formation. at the meantime, the amount of iron in the diet (pelet) may be inadequate to compensate the animals need for RBCs formation. It had been reported that patients with low serum ferritin had iron deficiency but normal $\mathrm{Hb}$ and PCV usually suffer from fatigue that reversed by iron treatment [21]. In rabbits treated with FA+MTX ferritin level increased significantly as compared with $\mathrm{M}$ and FA groups and decreased significantly as compared with control but the values approached to that of control. This may be due to the effect of (FA) on GIT to enhance the absorption of iron which lead to increase the formation of RBCs and $\mathrm{Hb}$ because dietary iron not enough [22].

Depending on this fact when ferritin decreased in the body, the absorption of free iron increased from GIT as possible as leading to increase serum iron. The high erythropoiesis process in F group as a result of erythropoietin hormone stimulation need more amount of iron which is probably inadequate in diet [22]

The total SI in FM group decreased significantly as compared with MTX group and increased significantly as compared with $\mathrm{C}$ and $\mathrm{F}$ groups. This could be explained according to the role of FA. For the TIBC which is the test request in iron deficiency anemia is evaluated, by adding the iron to blood sample for saturating the transferrin and the amount of iron bounded represents TIBC [22]. The TIBC increased highly significant in MTX group as compared with the other groups due to serum iron deficiency that resulting from malabsorption of iron from GIT as side effect of MTX treatment [21]. The increase in TIBC occurs to compensation the deficiency in iron or in the $\beta$-globulin protein "transferrin" that transports the iron.

TIBC - Tiron $=$ unbound iron binding capacity (UBIBC), which is the amount of iron excreted from the body without uses which highly increased in MTX group and decreased in F group due to the highly consumption of iron for the active erythropoiesis that stimulated by folic acid in F group. The small value of UBIBC in F group indicates that the deficiency in this group results from the consumption of iron for the erythropoiesis, and the deficiency in $\mathrm{M}$ group resulting from excretion of iron in high amount by the body due to no absorption of iron by the GIT, or no use by the body for erythropoiesis [17].
In addition, there is a significant decrease in bilirubin concentration of $\mathrm{M}$ group as compared with other groups and this may be due to decrease in the RBCs number and their $\mathrm{Hb}$ content which inturn lead to decreased destruction of fragile and abnormal megaloblastic erythroid precursor, this is coincided by bone marrow examination of the same group. Also, in FA group there is a significant increase in bilirubin concentration as compared with $\mathrm{M}$ group and a significant decrease as compared with $\mathrm{C}$ and FM groups. This could be explained by the effect of FA on RBCs which lead to produce healthy RBCs characterized by high resistant cell membrane [17]. It was concluded from this study that folic acid is administration with MTX very important to correct these changes and the animals return to normal conditions. More work is needed to study the effects of these drugs on other systems in the body.

Acknowledgment: To all staff in the departments of Physiology, Pharmacology and Biochemistry, Veterinary Medicine faculty, Department of Chemistry, Sciences Faculty, Tikrit University, and Department of Immediate Ambulance, AlDour Technical Institute, Northern Technical University, Salah-aldeen, Iraq

Funding statement: Self-funding.

Conflict of interest: Authors declare no conflict of interest.

Ethical consideration: The study was conducted according to the ethical standards and institutional guides that recorded in Instructions of the Ministry of Higher education and scientific research .

\section{References}

1. Zeller, J.L., Burke, A.E. and Glass, R.M. Folic Acid. JAMA., 296 (22),2758, pp1-1(2006). doi:10.1001/jama.296.22.2758.

2. Marry, W. Homocysteine folate and cardiovascular disease. Inter.J. Vit., 71,173-178 (2001).doi: 10.1024/0300-9831.71.3.173.

3. Kim, J.M., Stewart, B.R., Kin, S.W., Yang, S.J., Shin, I.S. and Yoon, J.S.Predictive value of folate, vitamin B12, and homocysteine levels in late-life depression. Br. J. Psychiatry, 192, 268-274 (2008).

4. Baltimore, M.D. Water Soluble Vitamins: folic acid. University of Maryland Medical Center. 22s . Green street.(2008). 
5. Greory, S. and Kelly, N.D. Folate: Supplemental Forms and Therapeutic Applications. Alternative Medicine Review, 10(3),223-229(2005).

6. Ratan, S.K., Rattan, K.N., Pandey, R.M., Singhal, S., Kharab, S. and Bala, M., Evaluation of the levels of folate, vitamin B12, homocysteine and fluoride in the parents and the affected neonates with neural tube defect and their matched controls. Pediatr. Surg. Lnt., 24, 803-808(2008).

7. Durga, J., van Boxtel, M.P., Schouten, E.G., Kok, F. J., Jolles, J. and Katan, M.B. Effect of 3-year folic acid supplementation on cognitive function in older audits in the FACIT trial; a randomized double blind, controlled trial. Lancet., 369, 208216(2007).

8. Monograph. Folic Acid. Thorne Research, Inc. All Rights Reserved. No Reprint Without Written Permission. Alternative Medicine Review, 10 (3), 222-229(2005)

9. Antony, A. C. Megaloblastic anemias. Ed. by Goldman,L.and Ausillo,D. 23rd Cecil Medicine. Philadelphia, Pa: Saunders Elsevier;chap. 170(2007).

10. Delea, V., Marco, A., Margant, G., Cinani, G., Zammerchi, E. and Setaccic A. Low dose folic acid supplementation reduces plasma level of the cardiovascular risk factors homocystein in postmenopausal women. Am .J. Obstet. Gynecol., 183,945-947(2002).

11. Johnston, A., Gudjonsson, J.E., Sigmundsdottir, H, Ludviksson, B. R. and Valdimarsson, H. The anti-inflammatory action of methotrexate is not mediated by lymphocyte apoptosis, but by the suppression of activation and adhesion molecules. Clin. Immunol.,114 (Feb.), 154-163(2005).

12. Fox, R.I. Sjögren's syndrome: Current therapies remain inadequate for a common disease. Expert Opinion on Investigational Drugs, 9(9), 20072016(2000).

13. Woo, S.P. Role of hyperhomocysteinemia in liver injury and abnormal lipid metabolism (protective effect of folic acid supplemintation), PH.D thesis. University of Manitoba.(2007).
14. Plumb D.C. Veterinary drug handbook, 3rd edition, Iowa state university pressl Amos: 479-482(1999).

15. Tietz, N.W. Clinical Guide to Laboratory Tests, $3^{\text {rd }}$ ed., W.B. Saunders Co., Philadelphia, PA. (1995).

16. Young, D.S. Effect of Drug on Clinical Laboratory Tests.4th Edition.AACC Press(1995).

17. Brockus, C.W. and Andreasen, C.B. Erythrocytes. In "Duncan \& Prasses. Veterinary Labrotory Medicine-Clinical Pathology. 4th edition. Latimer, K., S., Mahaffy, E., A. and Prasse, K., W. Blackwell publishing. Ch:1. pp.11-45. (2013).

18. Thrall, M. A.Veterinary Hematology and Clinical Chemistry. Lippincott Williams and Wilkins com. Philadelphia. U.S.A.(2004).

19. Boukhettala, N., Leblond, J., Claeyssens, S., Faure, M., Le Pessot, F., Bole-Feysot, C., Hassan, A., Mettraux, C., Vuichoud, J., Lavoinne, A., Breuille, D., Dechelotte, P. and Coeffier, M. Methotrexate induces intestinal mucositis and alter gut protein metabolism independently of reduced food intake". Am. J. Physiol. Endocrinol. Metab.296: E182E190, (2008).doi:10.1152/ajpendo.90459.2008.

20. Saegusa, Y., Ichikawa, T., Iwai, T., Goso, Y., Ikezawa, T., Nakano, M., Shikama, N., Saigenji, K. and Ishihara, K. Effect of acid antisecretory drugs on mucus barrier of the rat against 5-flurouracilinduced gastrointestinal mucositis. Scandinavian Journal of Gastroenterology, 43, 531-537(2018).

21. Mason, P. Whys, what's and whens of blood tests. The Pharmaceutical Journal. 272,419-421 (2014).

22. Ginder, G. Microcytic and hypochromic anemia. $23^{\text {rd }}$ ed., Edit by Goldman L, Ausiello D, eds. Cecil Medicine. Philadelphia, Pa: Saunders Elsevier;:chap 163.(2017). 


\section{تأثثير حامض الفوليك على بعض المعايير الكيموحيوية في إناث الأرانب المعالجة تجريبياً بالميثوتريكسات}

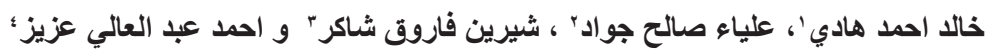

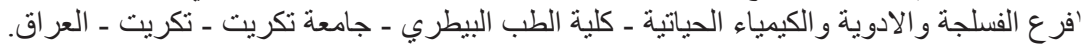

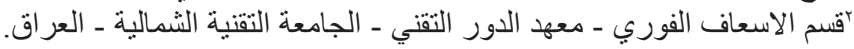

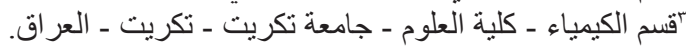

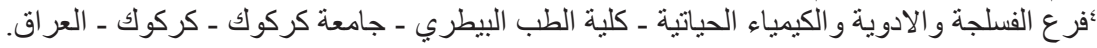

أجريت الدراسة الحالية لمعرفة تأثير حامض الفوليك على بعض المعايير الكيموحيوية لإناث الأرانب المعالجة

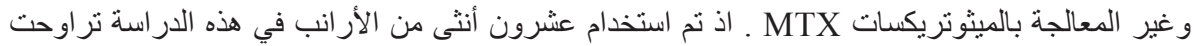

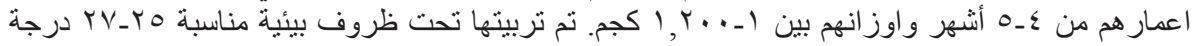

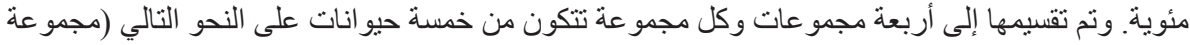

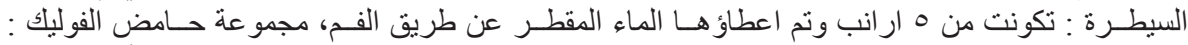

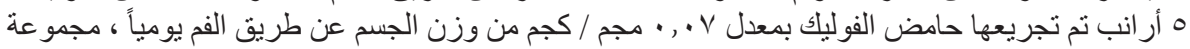

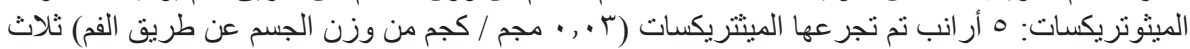

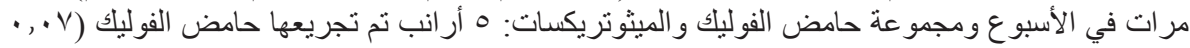

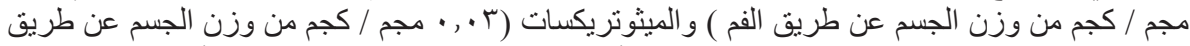

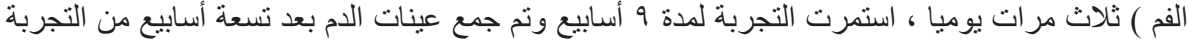

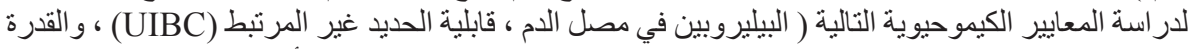

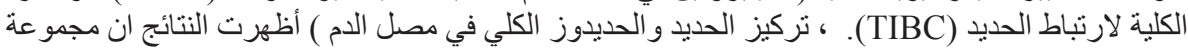

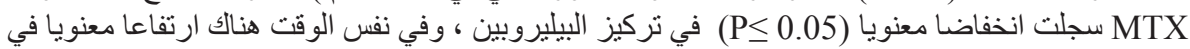

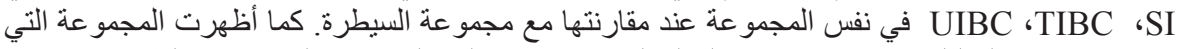

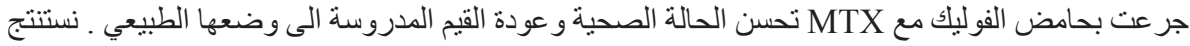

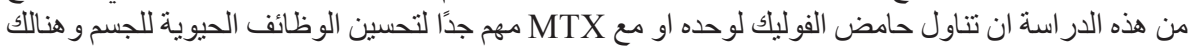
حاجة إلى مزيد من الدراسات لمعرفة آثار هذه الأدوية على أنظمة الجسم الاخرى.

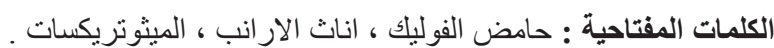

